\title{
Influence of Small Content Elements Additions on the Glass Forming Ability of Zr-based Bulk Metallic Glasses Alloys
}

\author{
Nelson Delfino de Campos Neto * ${ }^{*}$, Wesley Marques de Paula ${ }^{a}$, Flavio Soares Pereira ${ }^{a}$, Catherine \\ Jane Parrish ${ }^{b}$, Marcelo Falcão de Oliveira ${ }^{a}$ \\ ${ }^{a}$ Departamento de Engenharia de Materiais, Escola de Engenharia de Sao Carlos, Universidade de São \\ Paulo, Avenida João Dagnone, 1100, Jardim Santa Angelina, 13563-120, São Carlos, SP, Brasil \\ ${ }^{b}$ Boeing Pesquisa e Tecnologia, São José dos Campos, SP, Brasil
}

Received: December 12, 2017; Revised: April 24, 2018; Accepted: August 19, 2018

The present work reports investigation on the Glass Forming Ability (GFA) of Zr-based Bulk Metallic Glasses (BMG's) by microalloying with early transition metals. GFA was measured as the amorphous fraction formed in samples with different diameters using optical microscopy (OM) and image analysis techniques. Samples with the highest GFA had their oxygen content measured in a Leco RO-400. This study shows that additions of Molybdenum or Iron in $\mathrm{Zr}_{48} \mathrm{Cu}_{(48-\mathrm{x})} \mathrm{Al}_{4} \mathrm{M}_{\mathrm{x}}(\mathrm{M}=\mathrm{Mo}$ or $\mathrm{Fe}$ ) alloys resulted in a minor GFA improvement, but far from the results reported in the literature with $\mathrm{Nb}$ additions in this system. Niobium microalloying to $\mathrm{Zr}_{62} \mathrm{Cu}_{15.5} \mathrm{Al}_{10} \mathrm{Ni}_{(12.5-\mathrm{x})} \mathrm{Nb}_{\mathrm{x}}$ and $\left(\mathrm{Zr}_{55} \mathrm{Cu}_{30} \mathrm{Al}_{10}\right)_{100-}$ ${ }_{x} \mathrm{Nb}_{\mathrm{x}}$ alloys have a deleterious effect on the GFA. Oxygen measurements of $\left(\mathrm{Zr}_{55} \mathrm{Cu}_{30} \mathrm{Al}_{10}\right)_{99} \mathrm{Nb}_{1}$ and $\mathrm{Zr}_{62} \mathrm{Cu}_{15.5} \mathrm{Al}_{10} \mathrm{Ni}_{12.4} \mathrm{Nb}_{0.1}$ alloys have shown similar oxygen content, indicating that oxygen was not a limiting factor on this study. The amorphous fraction quantification from OM image analysis maintains the same fraction ratio from the heat released at the crystallization event from heating DSC analysis.

Keywords: Bulk Metallic Glasses, Rapid-solidification, Metallography, Glass Forming Ability, Oxygen.

\section{Introduction}

The application of Bulk Metallic Glasses (BMG) as engineering materials is the goal of many research teams spread around the globe. BMG have outstanding mechanical properties, compared to the conventional alloys, due to high strength ${ }^{1}$, resilience ${ }^{2}$, wear resistance ${ }^{3}$ and corrosion resistance ${ }^{4}$. In order to use BMGs in structural applications the research groups are investigating ways of increasing the Glass Forming Ability (GFA) and ductility of such alloys.

The literature shows that GFA and ductility can be both improved with the use of minor addition of elements, or microalloying technique 5 . Microalloying has improved the GFA of many BMG systems by stabilizing the amorphous phase $^{5}$, removing deleterious elements from the glass matrix ${ }^{6}$ or altering its crystallization kinetics ${ }^{7}$. The ductility of several alloys was increased by the compositional change ${ }^{8-9}$ or by the formation of a second phase ${ }^{10-11}$ embedded in the amorphous matrix.

The present work reports our investigation of microalloying effects on the GFA of Zr-based BMG, sharing some data to other groups and supporting the development of commercial BMG. Zr-based BMG was one of the first BMG to achieve amorphous diameters larger than $10 \mathrm{~mm}^{20}$ and nowadays it is the only commercially feasible, known as Vitreloy ${ }^{21}$. There is a vast literature of microalloying Zr-based BMG with early ${ }^{22}$ and late ${ }^{23}$ transition metals but very few studies with elements from the groups 5-8. This study has the objective of report the data of the microalloying effect of Molybdenum, Iron and Niobium upon the GFA of Zr-based BMG. The GFA was measured as the amorphous fraction formed in samples with different diameters by image analysis of optical microscopy and correlated with differential scanning calorimetry (DSC) and scanning electron microscopy (SEM). The oxygen content of the best glass formers was also measured showing that not only the GFA was improved but the oxygen deleterious effect was minimized.

\section{Experimental Procedure}

The present study was made considering glassy alloys of various compositions based on the $\mathrm{Zr}-\mathrm{Cu}-\mathrm{Al}$ system described by the general formulas (at. \%): $\mathrm{Zr}_{48} \mathrm{Cu}_{(48-\mathrm{x})} \mathrm{Al}_{4} \mathrm{M}_{\mathrm{x}}$ with $\mathrm{M}=\mathrm{Mo}$ or $\mathrm{Fe}$; $\mathrm{Zr}_{62} \mathrm{Cu}_{15.5} \mathrm{Al}_{10} \mathrm{Ni}_{(12.5-\mathrm{x})} \mathrm{Nb}_{\mathrm{x}}$; and $\left(\mathrm{Zr}_{55} \mathrm{Cu}_{30} \mathrm{Al}_{10}\right)_{100-\mathrm{x}} \mathrm{Nb}_{\mathrm{x}}$ where $\mathrm{x}$ could be equal to $0.1 ; 0.5 ; 1.0$; or 1.5 . This set of values was chosen in order to analyze the influence of microadditions of the presented elements on the GFA of the glassy alloys.

All alloys used in the present study were produced by arc-melting from their respective constituent high pure raw elements $(99 \%+)$, in a high purity argon atmosphere, on a copper hearth cooled bed with circulating room temperature water. Each initial ingot was arc-melted at least five times and flipped between steps to assure complete homogeneity. Afterwards, cylindrical specimens with diameters varying from 2 to $7 \mathrm{~mm}$ were produced by suction casting of the liquid metal into copper molds. 
The samples were cut in the cross-section using a diamond saw disc equipment for metallographic preparation. The samples were then embedded in polymeric resin and prepared for optical microscopy (OM), by grinding and polishing according to ASTM E3-11. The polishing step was performed on an automatic machine EcoMet 250 BUEHLER $\AA$ using 1 $\mu \mathrm{m}$ alumina suspension. Subsequently, the samples had their surfaces etched by immersing them in an etching solution of $\mathrm{HF}(0.8 \%$ wt. $), \mathrm{HNO}_{3}\left(14.6 \%\right.$ wt.) and $\mathrm{H}_{2} \mathrm{O}(84.6 \%$ wt.) for five seconds.

The OM analyses occurred by image acquisition of the samples etched surfaces. For that purpose, it was used the software Axion Vision AxioVs40 V4.8.2.0 in a Scope A.1 Zeiss microscope. The images obtained had their analysis based on ASTM E1245-95. The method consisted in the use of automatic software-controlled segmentation procedure to select and measure areas of interest in the images. In this case, these areas corresponded to the bright amorphous region. Once they were measured, it was possible to calculate its percentage considering the whole sample. Fig. 1 shows an example of measurement by image analysis. The red region corresponds to the amorphous fraction, while the green one is a region excluded from the analysis, i.e. sample mount and pores. The same quantification procedure was performed by 4 different trained operators in order to reduce the bias in the measurement method.

DSC analysis was made in four different alloys to evaluate and compare the results from image analysis with Enthalpy released during crystallization of these alloys. SEM back-scattered (BSE) images were acquired from two different alloys to confirm the presence of the amorphous phase detected by optical microscopy and quantified by image analysis.

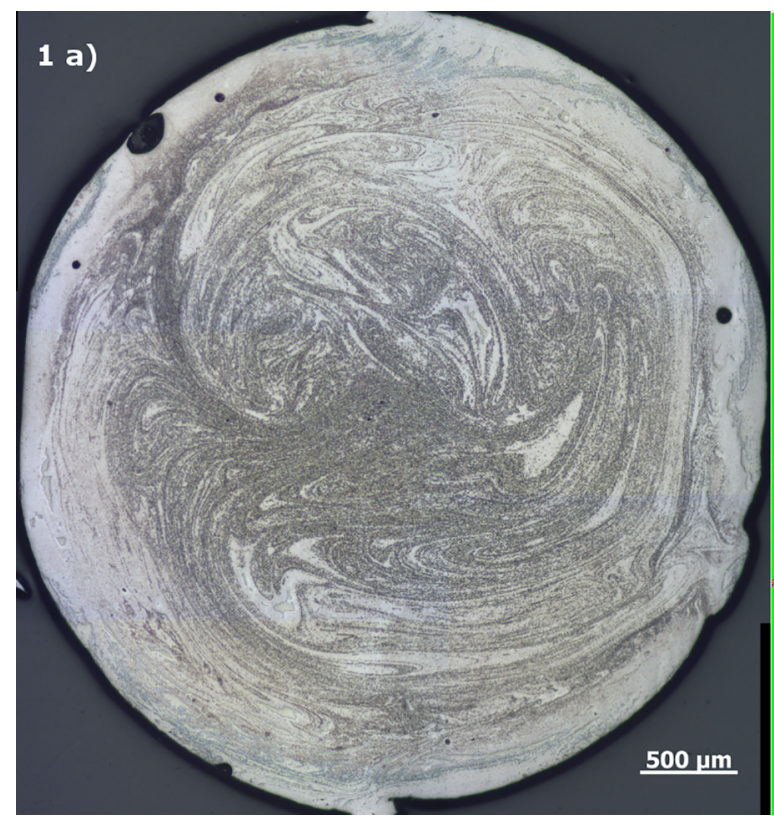

The samples with the higher GFA, measured by their amorphous fraction, had the oxygen content measured by hot extraction using the inert gas fusion principle in a LECO RO400 equipment following ASTM-E-1019. For that purpose, 9 pieces of around $0.1 \mathrm{~g}$ each were used in an oxygen free Ni basket. The oxygen levels of the samples were compared in order to evaluate any statistically significant difference among the samples.

\section{Results and Discussion}

\subsection{Optical microscopy analysis}

Table 1 shows the samples synthesized relating their composition with the respective diameters produced, in $\mathrm{mm}$.

The OM results of the amorphous fraction by the content of microalloying added for the $\mathrm{Zr}_{48} \mathrm{Cu}_{(48-\mathrm{x})} \mathrm{Al}_{4} \mathrm{M}_{\mathrm{x}}(\mathrm{M}=\mathrm{Mo}$ or $\mathrm{Fe}$ ) samples are shown in Fig. 2. Figure 2(a) correspond to $\mathrm{M}=\mathrm{Fe}$ and Figure $2 \mathrm{~b}$ ) to $\mathrm{M}=\mathrm{Mo}$. Figure 2(a) shows clearly that the addition of Fe has a negative effect on the GFA, independently of the amount of Fe added in the alloy, where by increasing the amount of Fe it leads to a decrease

Table 1. Composition and diameters (in $\mathrm{mm}$ ) of the samples produced for OM analysis.

\begin{tabular}{llccc}
\hline \multirow{2}{*}{ Composition } & \multicolumn{5}{c}{$\mathrm{x}$ (in at. \%) } \\
& 0.10 & 0.50 & 1.00 & 1.50 \\
\hline $\mathrm{Zr}_{48} \mathrm{Cu}_{(48-\mathrm{x})} \mathrm{Al}_{4} \mathrm{M}_{\mathrm{x}}$ & $2 ; 3 ; 4$ & $2 ; 3 ; 4$ & $2 ; 3 ; 4$ & 2 \\
where M = Fe or Mo & & & & \\
$\mathrm{Zr}_{62} \mathrm{Cu}_{15.5} \mathrm{Al}_{10} \mathrm{Ni}_{(12.5-\mathrm{x})}$ & $2 ; 3 ; 4 ;$ & $3 ; 4$ & $3 ; 4$ & $3 ; 4$ \\
$\mathrm{Nb}_{\mathrm{x}}$ & $5 ; 6 ; 7$ & & $2 ; 3 ; 4 ;$ & $5 ; 6 ; 7$ \\
$\left(\mathrm{Zr}_{55} \mathrm{Cu}_{30} \mathrm{Al}_{10}\right)_{100-\mathrm{x}} \mathrm{Nb}_{\mathrm{x}}$ & $5 ; 6 ; 7$ & $5 ; 6$ & $5 ; 6 ; 7$ & 5 \\
\hline
\end{tabular}

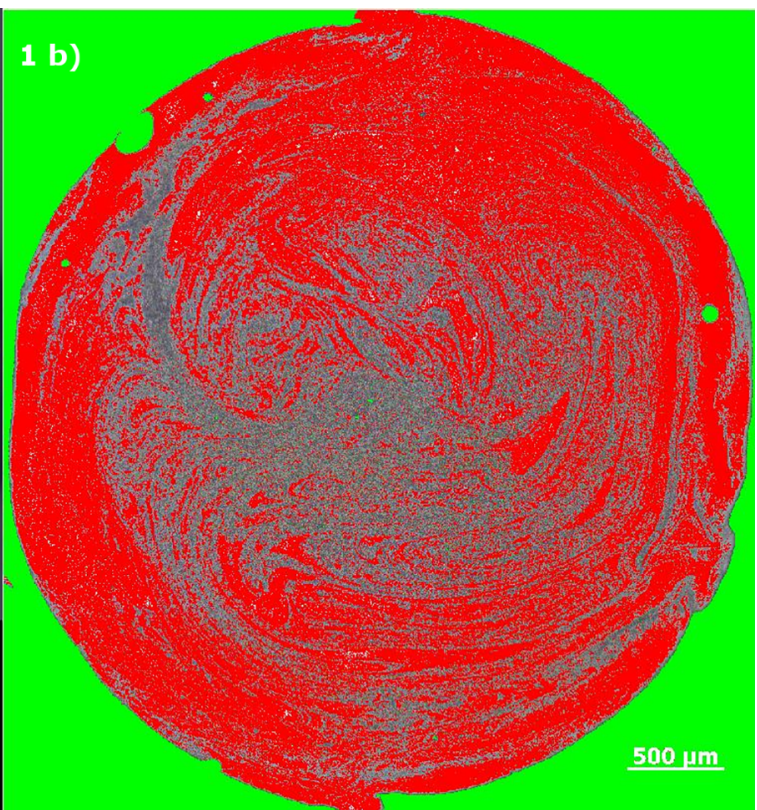

Figure 1. a) Optical micrograph and b) Example of the image analyzes process made in one of the samples. 

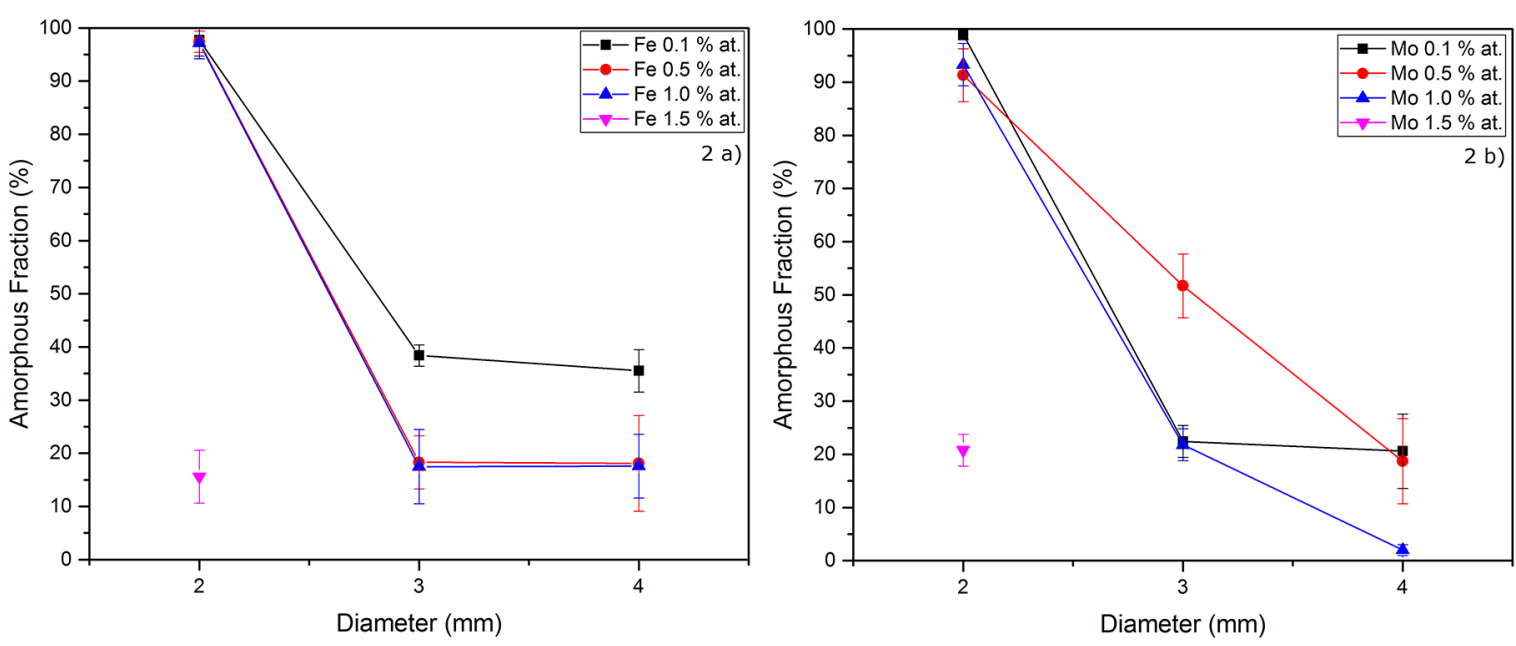

Figure 2. a) $\mathrm{Zr}_{48} \mathrm{Cu}_{(48-x)} \mathrm{Al}_{4} \mathrm{Fe}_{\mathrm{x}}$ with $\mathrm{x}=0.1,0.5,1.0$ and $1.5 \%$ at.; b) $\mathrm{Zr}_{48} \mathrm{Cu}_{(48-\mathrm{x} x)} \mathrm{Al}_{4} \mathrm{Mo}_{\mathrm{x}}$ with $\mathrm{x}=0.1,0.5,1.0$ and $1.5 \%$ at.

in the amorphous fraction. Figure 2(b), on the other hand, shows that an increase of the GFA happened with additions of Mo $0.5 \%$ at. For both cases, additions of $\mathrm{Fe}$ or Mo, when the value of microalloying was increased from 1.0 to 1.5 (at $\%$ ), even for $2 \mathrm{~mm}$ samples it was not observed a significant amorphous fraction, therefore, the parent composition was the limiting factor.

Figure 3 shows the comparison of our results with the same based alloy studied with different $\mathrm{Nb}$ amounts ${ }^{10,12-13}$. All the points were fixed for samples with $3 \mathrm{~mm}$ in diameter, as a base for comparison. It is possible to see that our samples with the addition of $\mathrm{Fe}$ and Mo resulted in alloys with the least amount of amorphous phase formed. This difference between our results and the literature has many possible explanations. The first, and most obvious, is the alloy composition which indicates that the $\mathrm{Nb}$ additions have a positive influence in the alloy's GFA over Fe and Mo additions. The other explanation can be related to the oxygen content in the samples. It is well-known that the oxygen has a strong influence on GFA of Zr-based $\mathrm{BMG}^{14-17}$. Once the literature used for the present comparison lacks the information about the oxygen content of the samples it is impossible to make an affirmation based only on the sample composition. Comparing the effect on GFA of our samples with the literature, the addition of $1 \mathrm{at} \%$ of $\mathrm{Nb}$ on the $\mathrm{Zr}_{48} \mathrm{Cu}_{(48-\mathrm{x})} \mathrm{Al}_{4} \mathrm{M}_{\mathrm{x}}$ seems to be the best option to enhance the GFA of this alloy.

The results for the composition of $\mathrm{Zr}_{62} \mathrm{Cu}_{15.5} \mathrm{Al}_{10} \mathrm{Ni}_{(12.5-\mathrm{x})}$ $\mathrm{Nb}_{x}$ can be seen in Fig. 4. For diameters above $4 \mathrm{~mm}$, the amorphous fraction measured was not significant, below $30 \%$. When considering 3 and $4 \mathrm{~mm}$ diameter samples however, it was possible to notice that the glass content decreased as the value of the microalloying element increased. In other words, more additions of $\mathrm{Nb}$ tend to affect negatively the GFA. It is possible to assume that the critical cooling rate $(\mathrm{Rc})$ value for this composition increases drastically. The base alloy $\mathrm{Zr}_{62} \mathrm{Cu}_{15.5} \mathrm{Al}_{10} \mathrm{Ni}_{(12.5-\mathrm{x})} \mathrm{Nb}_{\mathrm{x}}$, with $\mathrm{x}=0$, is reported

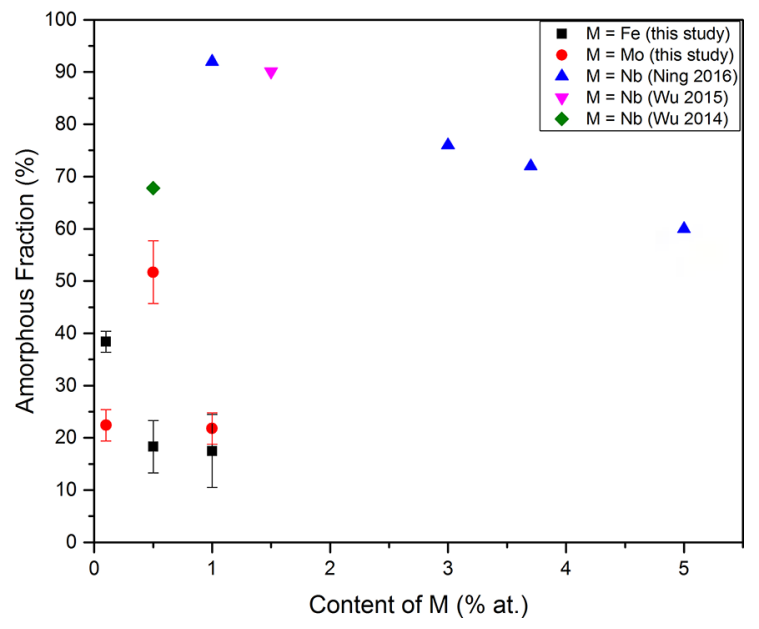

Figure 3. Correlation between amorphous fraction and content of elements added for samples of $3.0 \mathrm{~mm}$ in diameter and general composition $\mathrm{Zr}_{48} \mathrm{Cu}_{(48-\mathrm{x})} \mathrm{Al}_{4} \mathrm{M}_{\mathrm{x}}(\mathrm{M}=\mathrm{Fe}, \mathrm{Mo}, \mathrm{Nb})$. Collected from ${ }^{10,12-13}$

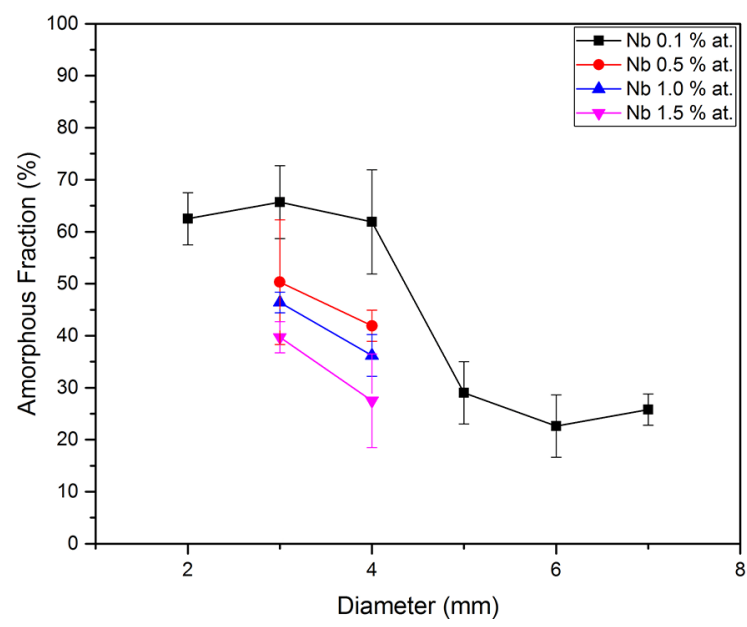

Figure 4. Correlation between amorphous fraction measured by OM and content of elements added for samples of general composition $\mathrm{Zr}_{62} \mathrm{Cu}_{15.5} \mathrm{Al}_{10} \mathrm{Ni}_{(12.5-\mathrm{x})} \mathrm{Nb}_{\mathrm{x}}$. 
to be feasible to produce a fully amorphous rod up to $5 \mathrm{~mm}$ in diameter ${ }^{18}$. In this study, we have found around $30 \%$ of amorphous fraction for the case of $\mathrm{Nb}$ addition $(0.1 \mathrm{at} \%)$ at $5 \mathrm{~mm}$. Therefore, it is possible to extrapolate that the addition of $\mathrm{Nb}$ on the base alloy has not a positive effect.

Fig. 5 displays the results of OM quantification of $\left(\mathrm{Zr}_{55} \mathrm{Cu}_{30} \mathrm{Al}_{10}\right)_{100-\mathrm{x}} \mathrm{Nb}_{\mathrm{x}}$ samples. As can be seen 5, 6 and 7 $\mathrm{mm}$ diameter samples presented amorphous content smaller than $30 \%$ for practically any content of $\mathrm{Nb}$. A good result in terms of amorphous fraction was only observed for $\mathrm{Nb}=1.0 \%$ and $2 \mathrm{~mm}$ diameter sample, meaning that our equipment was able to achieve cooling rates closer to the Rc of the alloy. When analyzing 3 and $4 \mathrm{~mm}$ samples, the amorphous fraction was measured between 47.5 and $67.5 \%$ for $\mathrm{Nb}=1.0 \%$. One drawback related to $\mathrm{OM}$ quantification in samples with larger diameters is that the resolution decreases with the increase of sample size.

\subsection{Oxygen content measurement}

The compositions with the higher GFA had their oxygen content measured and the results are shown in Fig. 6. For each sample, there were 9 measurements of oxygen content. The difference in average oxygen measured in these 2 different alloys cannot be based on the difference of the Zirconium masses between the two alloys as proposed previously ${ }^{19}$. The two sample t-test failed to reject the null hypothesis. The alloy $\left(\mathrm{Zr}_{55} \mathrm{Cu}_{30} \mathrm{Al}_{10}\right)_{99} \mathrm{Nb}_{1}$ has an average of $922 \mathrm{ppm}$ of oxygen and a large dispersion compared to the alloy $\mathrm{Zr}_{62} \mathrm{Cu}_{15.5} \mathrm{Al}_{10} \mathrm{Ni}_{12.4} \mathrm{Nb}_{0.1}$, with an average of $981 \mathrm{ppm}$ of oxygen. These results shows that both alloys have the same oxygen content within a $95 \%$ confidence interval.

\subsection{Scanning electron microscopy and differential scanning calorimetry}

Figure 7 shows two BSE images from $3 \mathrm{~mm}$ samples of the alloys a) $\mathrm{Zr}_{48} \mathrm{Cu}_{47.9} \mathrm{Al}_{4} \mathrm{Fe}_{0.1}$ and b) $\mathrm{Zr}_{48} \mathrm{Cu}_{47.5} \mathrm{Al}_{4} \mathrm{Mo}_{0.5}$. From

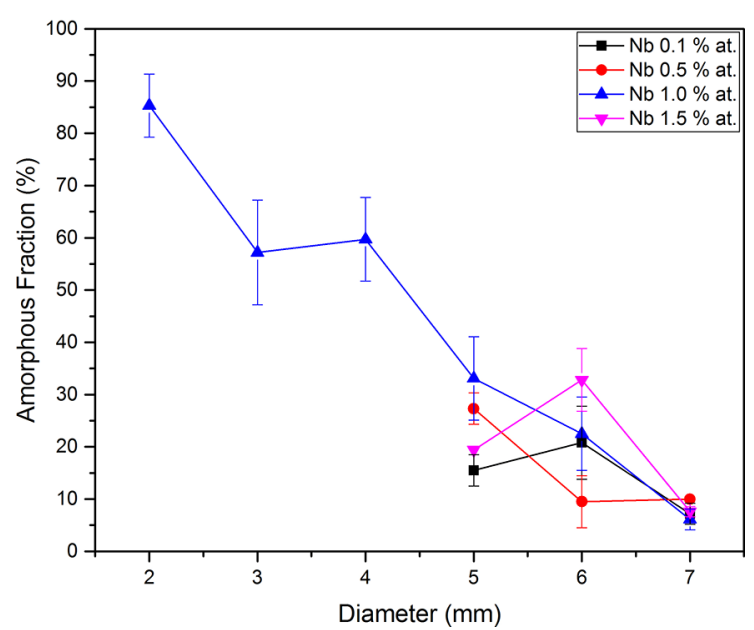

Figure 5. Correlation between amorphous fraction measured by OM and content of elements added for samples of general composition $\left(\mathrm{Zr}_{55} \mathrm{Cu}_{30} \mathrm{Al}_{10}\right)_{100-\mathrm{x}} \mathrm{Nb}_{\mathrm{x}}$. the images it is clear the presence of a brighter amorphous matrix and darker crystalline phases. The same samples were analyzed by DSC and the results are showed at Table 2 and Figure 8, where the ratio of heat released in the crystallization event is the same as from the ratio of amorphous fraction quantification by $\mathrm{OM}$ image analysis. The samples from 3 $\mathrm{mm}\left(\mathrm{Zr}_{55} \mathrm{Cu}_{30} \mathrm{Al}_{10}\right)_{99} \mathrm{Nb}_{1}$ and $6 \mathrm{~mm}\left(\mathrm{Zr}_{55} \mathrm{Cu}_{30} \mathrm{Al}_{10}\right)_{98.5} \mathrm{Nb}_{1.5}$ alloys are also being showed at Table 2 and Figure 8 , and the same effect of ratio in the heat released in the crystallization event was the same as from the ratio of amorphous fraction quantification by OM image analysis in these samples. This supports that the amorphous fraction quantification by $\mathrm{OM}$ image analysis is a cheaper and valid process for measuring the GFA from the alloys that maintains the same fraction ratio from the heat released at the crystallization event from heating DSC analysis.

\section{Conclusions}

The present study performed on $\mathrm{Zr}_{48} \mathrm{Cu}_{(48-\mathrm{x})} \mathrm{Al}_{4} \mathrm{M}_{\mathrm{x}}$, where $\mathrm{M}=\mathrm{Fe}$ or Mo, showed that the addition of this elements decrease the alloy's GFA. The GFA of the $\mathrm{Zr}_{48} \mathrm{Cu}_{(48-\mathrm{x})} \mathrm{Al}_{4} \mathrm{M}_{\mathrm{x}}$ system have been successfully improved with $\mathrm{M}=\mathrm{Nb}$ as reported in the literature ${ }^{10,12-13}$. Therefore, our results show that the use of $\mathrm{Fe}$ or Mo is not a viable alternative. In the second part of our study, we tried to investigate whether the GFA improvement by the $\mathrm{Nb}$ microalloying could be extended to other $\mathrm{Zr}$-based systems. Our results show that the addition of $\mathrm{Nb}$ from 0.1 at.\% to 1.5 at.\% in the $\mathrm{Zr}_{62} \mathrm{Cu}_{15.5} \mathrm{Al}_{10} \mathrm{Ni}_{(12.5-\mathrm{x})} \mathrm{Nb}_{\mathrm{x}}$ and the $\left(\mathrm{Zr}_{55} \mathrm{Cu}_{30} \mathrm{Al}_{10}\right)_{100-\mathrm{x}} \mathrm{Nb}_{\mathrm{x}}$ alloys have a deleterious effect on the alloys' GFA. Thus, the GFA improvement by the $\mathrm{Nb}$ microalloying is not an inherent feature on $\mathrm{Zr}$-based BMG.

The oxygen measurements of the $\left(\mathrm{Zr}_{55} \mathrm{Cu}_{30} \mathrm{Al}_{10}\right)_{99} \mathrm{Nb}_{1}$ and $\mathrm{Zr}_{62} \mathrm{Cu}_{15.5} \mathrm{Al}_{10} \mathrm{Ni}_{12.4} \mathrm{Nb}_{0.1}$ alloys have shown that the higher content of $\mathrm{Zr}$ in the later alloy do not increase the tendency to be contaminated with oxygen. This hypothesis has been raised in a previous study ${ }^{19}$ where the higher oxygen content

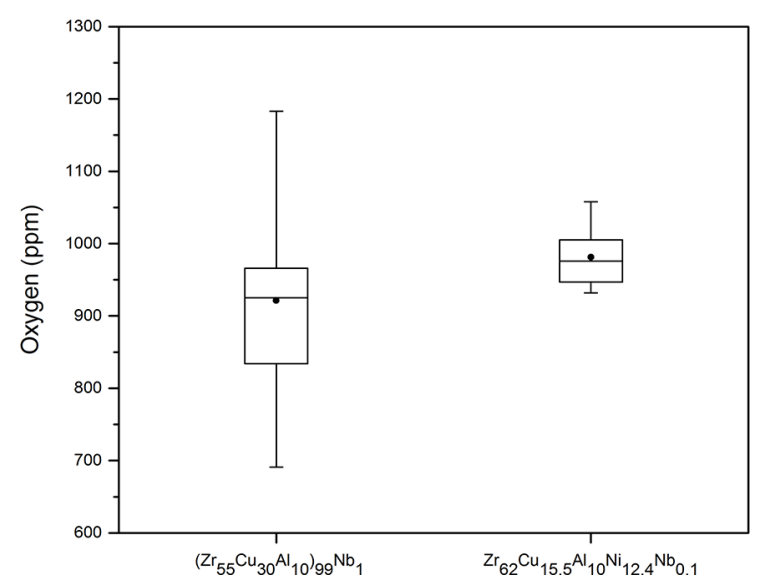

Figure 6. Boxplot comparing the oxygen content of the alloys with best GFA 

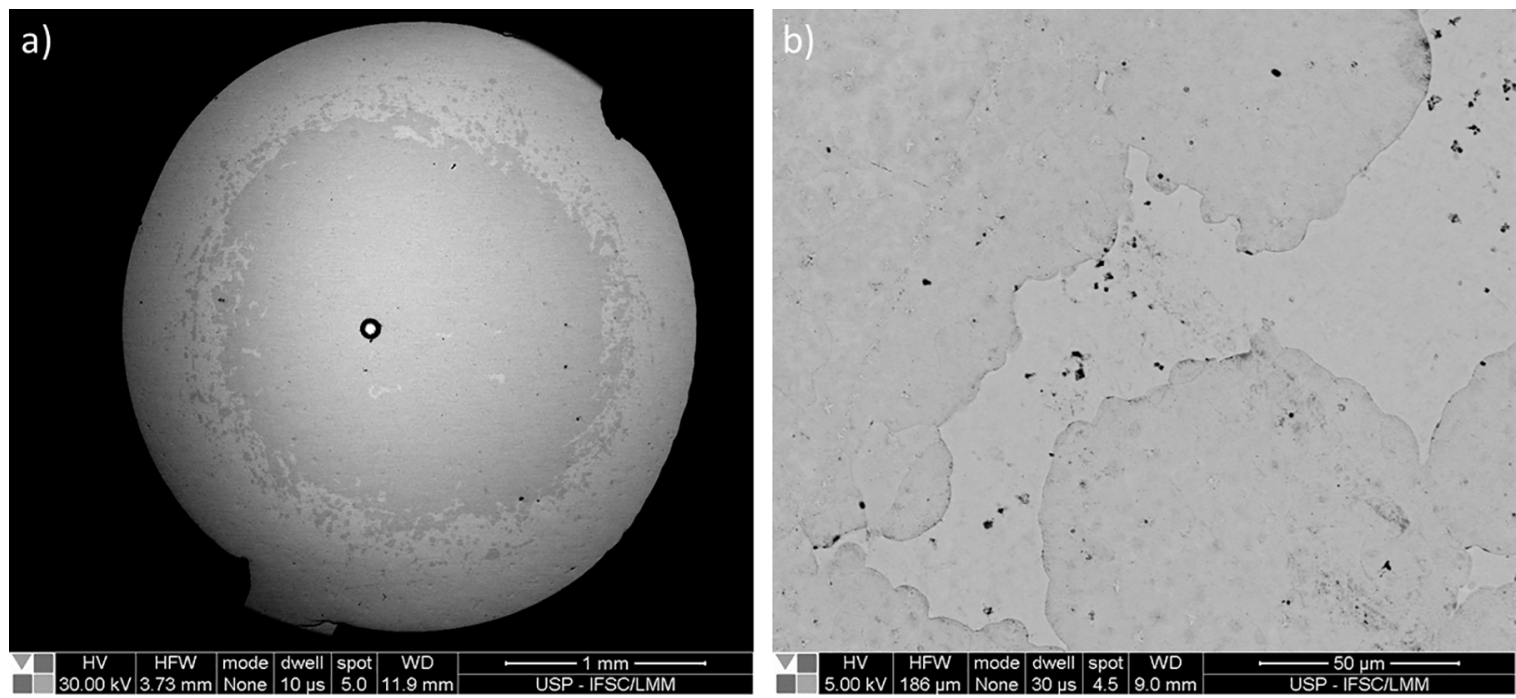

Figure 7. SEM BSE images from a) $\mathrm{Zr}_{48} \mathrm{Cu}_{47.9} \mathrm{Al}_{4} \mathrm{Fe}_{0.1}$ and b) $\mathrm{Zr}_{48} \mathrm{Cu}_{47.5} \mathrm{Al}_{4} \mathrm{Mo}_{0.5}$.

Table 2. DSC analysis showing the characteristic temperatures from the alloys, where the temperatures $\mathrm{T}_{\mathrm{g}}=$ glass transition; $\mathrm{T}_{\mathrm{x}}=$ crystallization; $\Delta \mathrm{T}_{\mathrm{x}}=$ supercooled liquid region; $\Delta \mathrm{H}_{\mathrm{x}}=$ enthalpy at crystallization.

\begin{tabular}{|c|c|c|c|c|c|}
\hline Alloys & $\mathrm{D}(\mathrm{mm})$ & $\boldsymbol{T}_{g}(\mathrm{~K})$ & $\boldsymbol{T}_{x}(\mathrm{~K})$ & $\Delta \boldsymbol{T}_{x}(\mathrm{~K})$ & $\Delta \boldsymbol{H}_{x}(\mathrm{~J} / \mathrm{g})$ \\
\hline $\mathrm{Zr}_{48} \mathrm{Cu}_{47.9} \mathrm{Al}^{4} \mathrm{Fe}_{0.1}$ & 3 & 656 & 744 & 88 & 30.2 \\
\hline $\mathrm{Zr}_{48} \mathrm{Cu}_{47.5} \mathrm{Al}_{4} \mathrm{Mo}_{0.5}$ & 3 & 650 & 744 & 94 & 41.7 \\
\hline$\left(\mathrm{Zr}_{55} \mathrm{Cu}_{30} \mathrm{Al}_{10}\right)_{99} \mathrm{Nb}_{1.0}$ & 3 & 665 & 733 & 68 & 54.4 \\
\hline$\left(\mathrm{Zr}_{55} \mathrm{Cu}_{30} \mathrm{Al}_{10}\right)_{98.5} \mathrm{Nb}_{1.5}$ & 6 & 662 & 735 & 73 & 27.8 \\
\hline
\end{tabular}

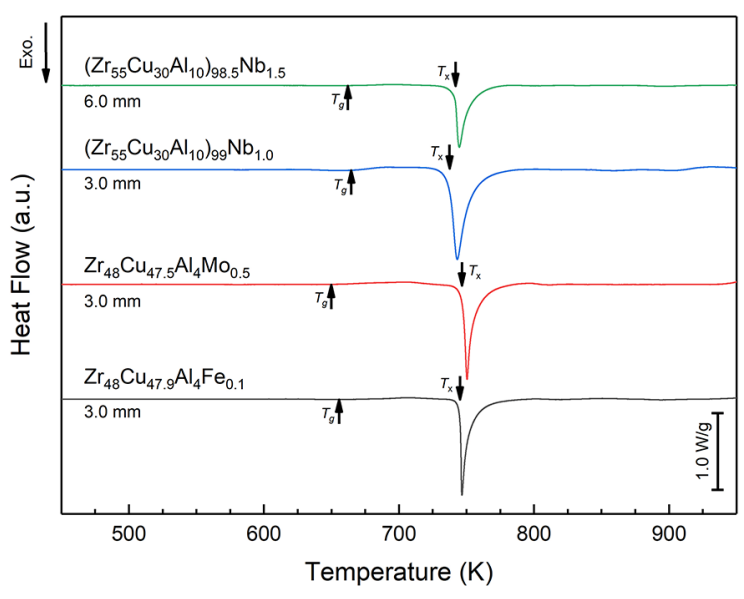

Figure 8. DSC heating curves for $3 \mathrm{~mm} \mathrm{Zr}_{48} \mathrm{Cu}_{479} \mathrm{Al}_{4} \mathrm{Fe}_{0.1}$, $\mathrm{Zr}_{48} \mathrm{Cu}_{47.5} \mathrm{Al}_{4} \mathrm{Mo}_{0.5},\left(\mathrm{Zr}_{55} \mathrm{Cu}_{30} \mathrm{Al}_{10}\right)_{99} \mathrm{Nb}_{1}$ and $6 \mathrm{~mm}\left(\mathrm{Zr}_{55} \mathrm{Cu}_{30} \mathrm{Al}_{10}\right)_{98.5} \mathrm{Nb}_{1.5}$.

of the alloys with higher $\mathrm{Zr}$ content would be explained by the $\mathrm{Zr}$ gettering nature.

The amorphous fraction quantification by OM image analysis is a cheaper and valid process for measuring the GFA from the alloys that maintains the same fraction ratio from the heat released at the crystallization event from heating DSC analysis.

\section{Acknowledgements}

The authors would like to thank Boeing Research \& Technology Brazil (BR\&T-Brazil) for the support for this research and for support of the University of Sao Paulo - Sao Carlos School of Engineering (EESC).

\section{References}

1. Zhu SL, Wang XM, Inoue A. Glass-forming ability and mechanical properties of Ti-based bulk glassy alloys with large diameters of up to $1 \mathrm{~cm}$. Intermetallics. 2008;16(8):1031-1035. DOI: $10.1016 /$ j.intermet.2008.05.006

2. Xie Z, Zhang Y, Yang Y, Chen X, Tao P. Effects of rare-earth elements on the glass-forming ability and mechanical properties of Cu46Zr47-x A17M x (M = Ce, Pr, Tb, and Gd) bulk metallic glasses. Rare Metals. 2010;29(5):444-450. DOI: 10.1007/ s12598-010-0147-7

3. Zhai F, Pineda E, Duarte MJ, Crespo D. Role of $\mathrm{Nb}$ in glass formation of Fe-Cr-Mo-C-B-Nb BMGs. Journal of Alloys and Compounds. 2014;604:157-163. DOI: 10.1016/j. jallcom.2014.03.095

4. Guo SF, Chan KC, Jiang XQ, Zhang HJ, Zhang DF, Wang JF, et al. Atmospheric RE-free Mg-based bulk metallic glass with high bio-corrosion resistance. Journal of Non-Crystalline Solids. 2013;379:107-111. DOI: 10.1016/j.jnoncrysol.2013.07.036 
5. Deng L, Zhou B, Yang H, Jiang X, Jiang B, Zhang X. Roles of minor rare-earth elements addition in formation and properties of $\mathrm{Cu}-\mathrm{Zr}-\mathrm{Al}$ bulk metallic glasses. Journal of Alloys and Compounds. 2015;632:429-434. DOI: 10.1016/j. jallcom.2015.01.036

6. Park JM, Park JS, Na JH, Kim DH, Kim DH. Effect of Y addition on thermal stability and the glass forming ability in Fe-Nb-B-Si bulk glassy alloy. Materials Science and Engineering: A. 2006;435-436:425-428. DOI: 10.1016/j. msea.2006.07.073

7. Jang JSC, Tseng CC, Chang LJ, Chang CF, Lee WJ, Huang JC, et al. Glass Forming Ability and Thermal Properties of the Mg-Based Amorphous Alloys with Dual Rare Earth Elements Addition. Materials Transactions. 2007;48(7):1684-1688. DOI: $10.2320 /$ matertrans.MJ200738

8. Chen J, Zhang Y, He JP, Yao KF, Wei BC, Chen GL. Metallographic analysis of $\mathrm{Cu}-\mathrm{Zr}$-Al bulk amorphous alloys with yttrium addition. Scripta Materialia. 2006;54(7):13511355. DOI: 10.1016/j.scriptamat.2005.12.002

9. Luo J, Duan H, Ma C, Pang S, Zhang T. Effects of Yttrium and Erbium Additions on Glass-Forming Ability and Mechanical Properties of Bulk Glassy Zr-Al-Ni-Cu Alloys. Materials Transactions. 2006;47(2):450-453. DOI: 10.2320/ matertrans.47.450

10. Wu FF, Chan KC, Jiang SS, Chen SH, Wang G. Bulk metallic glass composite with good tensile ductility, high strength and large elastic strain limit. Scientific Reports. 2014;4:5302. DOI: $10.1038 /$ srep05302

11. Cheng JL, Chen G, Liu CT, Li Y. Innovative approach to the design of low-cost Zr-based BMG composites with good glass formation. Scientific Reports. 2013;3:2097. DOI: 10.1038/ srep02097

12. Ning Z, Liang W, Zhang M, Li Z, Sun H, Liu A, et al. High tensile plasticity and strength of a CuZr-based bulk metallic glass composite. Materials \& Design. 2016;90:145-150. DOI: http://dx.doi.org/10.1016/j.matdes.2015.10.117

13. Wu FF, Chan KC, Chen SH, Jiang SS, Wang G. ZrCu-based bulk metallic glass composites with large strain-hardening capability. Materials Science and Engineering: A . 2015;636:502506. DOI: http://dx.doi.org/10.1016/j.msea.2015.04.027
14. Castellero A, Bossuyt S, Stoica M, Deledda S, Eckert J, Chen GZ, et al. Improvement of the glass-forming ability of $\mathrm{Zr}_{55} \mathrm{Cu}_{30} \mathrm{Al}_{10} \mathrm{Ni}_{5}$ and $\mathrm{Cu}_{47} \mathrm{Ti}_{34} \mathrm{Zr}_{11} \mathrm{Ni}_{8}$ alloys by electro-deoxidation of the melts. Scripta Materialia. 2006;55(1):87-90. DOI: 10.1016/j. scriptamat.2006.03.032

15. Gebert A, Eckert J, Schultz L. Effect of oxygen on phase formation and thermal stability of slowly cooled $\mathrm{Zr}_{65} \mathrm{Al}_{7.5} \mathrm{Cu}_{17.5} \mathrm{Ni}_{10}$ metallic glass. Acta Materialia. 1998;46(15):5475-5482. DOI: https://doi. org/10.1016/S1359-6454(98)00187-6

16. Liu CT, Chisholm M, Miller MK. Oxygen impurity and microalloying effect in a Zr-based bulk metallic glass alloy. Intermetallics. 2002;10(11-12):1105-1112. DOI: https://doi.org/10.1016/S09669795(02)00131-0

17. Kündig AA, Lepori D, Perry AJ, Rossmann S, Blatter A, Dommann A, et al. Influence of Low Oxygen Contents and Alloy Refinement on the Glass Forming Ability of $\mathrm{Zr}_{52.5} \mathrm{Cu}_{17.9} \mathrm{Ni}_{14.6} \mathrm{Al}_{10} \mathrm{Ti}_{5}$. Materials Transactions. 2002;43(12):3206-3210. DOI: http://doi.org/10.2320/ matertrans. 43.3206

18. Liu YH, Wang G, Wang RJ, Zhao DQ, Pan MX, Wang WH. Super Plastic Bulk Metallic Glasses at Room Temperature. Science. 2007;315(5817):1385-1388. DOI: 10.1126/science.1136726

19. Déo LP, de Oliveira MF. Accuracy of a selection criterion for glass forming ability in the $\mathrm{Ni}-\mathrm{Nb}-\mathrm{Zr}$ system. Journal of Alloys and Compounds. 2014;615(Suppl 1):S23-S28. DOI: https://doi. org/10.1016/j.jallcom.2013.11.194

20. Peker A, Johnson WL. A highly processable metallic glass: $\mathrm{Zr}_{41.2} \mathrm{Ti}_{13.8} \mathrm{Cu}_{12.5} \mathrm{Ni}_{10.0} \mathrm{Be}_{22.5}$. Applied Physics Letters. 1993;63(17):23422344 .

21. Andreoli AF, Ponsoni JB, Soares C, de Oliveira MF, Kiminami CS. Resistance upset welding of Zr-based bulk metallic glasses. Journal of Materials Processing Technology. 2018;255:760-764. DOI: 10.1016/j.jmatprotec.2018.01.034

22. Xi XK, Wang RJ, Zhao DQ, Pan MX, Wang WH. Glass-forming $\mathrm{Mg}-\mathrm{Cu}-\mathrm{RE}(\mathrm{RE}=\mathrm{Gd}, \mathrm{Pr}, \mathrm{Nd}, \mathrm{Tb}, \mathrm{Y}$, and Dy) alloys with strong oxygen resistance in manufacturability. Journal of Non-Crystalline Solids. 2004;344(3):105-109. DOI: 10.1016/j.jnoncrysol.2004.07.056

23. Conner RD, Maire RE, Johnson WL. Effect of oxygen concentration upon the ductility of amorphous $\mathrm{Zr}_{57} \mathrm{Nb}_{5} \mathrm{Al}_{10} \mathrm{Cu}_{15.4} \mathrm{Ni}_{12.6}$. Materials Science and Engineering: A. 2006;419(1-2):148-152. DOI: 10.1016/j.msea.2005.12.009 